\title{
A historical prospective study of European stainless steel, mild steel, and shipyard welders
}

L Simonato, A C Fletcher, A Andersen, K Anderson, N Becker, J Chang-Claude, G Ferro, M Gérin, C N Gray, K S Hansen, P-L Kalliomäki, K Kurppa, S Långard, F Merló, J J Moulin, M L Newhouse, J Peto, E Pukkala, B Sjögren, P Wild, R Winkelmann, R Saracci

\section{Abstract}

A multicentre cohort of 11092 male welders from 135 companies located in nine European countries has been assembled with the aim of investigating the relation of potential cancer risk, lung cancer in particular, with occupational exposure. The observation period and the criteria for inclusion of welders varied from country to country. Follow up was successful for $96.9 \%$ of the cohort and observed numbers of deaths (and for some countries incident cancer cases) were compared with expected numbers calculated from national reference rates. Mortality and cancer incidence ratios were analysed by cause category, time since first exposure, duration of employment, and estimated cumulative dose to total fumes, chromium (Cr), Cr VI, and nickel (Ni). Overall a statistically significant excess was reported for mortality from lung cancer (116 observed $v$ 86.81 expected deaths, SMR = 134). When analysed by type of welding an increasing pattern with time since first exposure was present for both mild steel and stainless steel welders, which was more noticeable for the subcohort of predominantly stainless steel welders. No clear relation was apparent between mortality from lung cancer and duration of exposure to or estimated cumulative dose of $\mathrm{Ni}$ or $\mathrm{Cr}$. Whereas the patterns of lung cancer mortality in these results suggest that the risk of lung cancer is higher for stainless steel than mild steel welders the different level of risk for these two categories of welding exposure cannot be quantified with precision. The report of five deaths from pleural mesothelioma unrelated to the type of welding draws attention to the risk of exposure to asbestos in welding activities.

International Agency for Research on Cancer, 150 Cours A Thomas, 69372 Lyon, France

R Saracci

See Appendix for affiliations of other authors
The first study reporting an increased risk for lung cancer among welders was the case-control study by Breslow et al. ${ }^{1}$ Since that time, several case-control studies of lung cancer have reported findings for welders, ${ }^{2-12}$ and a number of cohort studies of welders' mortality have been carried out. ${ }^{13-24}$ Most of these studies, along with several analyses of routine mortality data, have reported excesses of mortality from lung cancer ranging from $30 \%$ to $50 \%$. Few studies, however, have investigated the potential carcinogenic effect of exposures to specific welding fumes. They have been reviewed by Peto $^{25}$ and by the International Agency for Research on Cancer (IARC). ${ }^{26}$

Welders are exposed to welding fume, which in the case of stainless steel welding contains the carcinogens nickel $(\mathrm{Ni})$ and chromium $(\mathrm{Cr})$. Also, some welders are at risk of exposure to asbestos (particularly in shipyards) and suspected carcinogens such as silica dust. ${ }^{27}$ Many earlier studies did not subdivide welders by type of exposure; therefore the major aim of this study has been the separation of stainless steel welders, potentially exposed to $\mathrm{Cr}$ and $\mathrm{Ni}$, from mild steel welders and welders in shipyards.

This historical prospective study is unable, as in most such studies, to measure the potential confounding effect of smoking habits.

The IARC coorganised with the European Regional Offiice of the World Health Organisation (WHO/EURO) and the Danish Welding Institute a conference on welding in February $1985 .{ }^{28}$ At the same time WHO/EURO in collaboration with the Danish Welding Institute established a network of investigators conducting studies in three areas, with the aim of standardising and improving research methods. The areas were mortality and cancer incidence studies, morbidity studies, and assessment of industrial exposure through hygiene and biological monitoring.

Several cohort studies were already under way or at the planning stage, although each was of limited size. To increase the statistical power of the study it was agreed to carry out a formal pooling of these data at IARC. The purpose of the study was to update and to aggregate the information on mortality and in- 
Table 1 Inclusion criteria for each national cohort of welders

\begin{tabular}{|c|c|c|c|c|}
\hline \multicolumn{2}{|c|}{ Country } & \multirow{2}{*}{$\begin{array}{l}\text { Minimum duration } \\
\text { One year between } 1 \text { April } 1964 \text { and } \\
31 \text { December } 1984\end{array}$} & \multirow{2}{*}{$\begin{array}{l}\text { Started } \\
\text { Before } 1984\end{array}$} & \multirow{2}{*}{$\begin{array}{l}\text { In employment } \\
\text { In } 1964 \text { or later }\end{array}$} \\
\hline 01 & Denmark & & & \\
\hline 02 & England & Five years & - & In 1960 in factory 17 \\
\hline 03 & Finland & One year & - & - \\
\hline 04 & France & - & - & In 1975 or 1976 \\
\hline 05 & Germany & - & Before 1971 & 一 \\
\hline 06 & Italy & 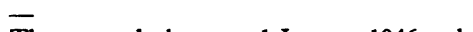 & $\overline{0}$ & - \\
\hline 07 & Norway & $\begin{array}{l}\text { Three months between } 1 \text { January } 1946 \text { and } \\
31 \text { December } 1976\end{array}$ & Before 1977 & After 1946 \\
\hline 08 & Scotland & Five years & 一 & $\begin{array}{l}\text { In } 1970 \text { in factory } 01 \\
\text { In } 1960 \text { in factory } 17 \\
\text { In } 1971 \text { in factory } 21\end{array}$ \\
\hline 09 & Sweden & Five years between 1950 and 1965 & Before 1961 & $\begin{array}{l}\text { Between } 1950 \text { and } \\
1965\end{array}$ \\
\hline
\end{tabular}

cidence of cancer among welders in several European countries, and to investigate the relation between the different types of exposure occurring in stainless steel, mild steel, and shipyard welding, and various sites of cancer, with particular emphasis on cancer of the lung.

\section{Materials and methods}

The population under study comprises workers employed as welders in 135 companies located in nine European countries. Both existing and newly collected data sets contribute to the common database.

Data on occupational history (including type of welding if known), vital state, cause of death, and when available, cancer registration, were supplied to IARC using a standardised protocol. The criteria for inclusion in the cohort were different from country to country depending on the availability of the data and on the study design, and table 1 lists these criteria.

Table 2 presents data on exclusions. Out of 12119 subjects received at IARC, 11092 were included in the cohort. Of the 1027 subjects excluded, 230 $(22.4 \%)$ belonged to factories too small or of too recent start of production to be included, 667 $(64.9 \%)$ did not meet the inclusion criteria, and 130
$(12.7 \%)$ had at least one element of essential information missing. Only men were included in the study.

One thousand and ninety three deaths were recorded at the end of the follow up and $338(3 \cdot 1 \%)$ subjects could not be traced or had emigrated.

Table 3 reports the vital state in detail by country.

Despite the different mechanisms operating in the various countries the completeness of the follow up $(96.9 \%)$ can be considered satisfactory. Data subdivided by country are not presented, although the contribution to observed deaths and cancer cases varies appreciably by country due to variation in both the size and the age structure of the study population. Age and sex specific national mortality reference rates have been computed at IARC using the WHO mortality data bank. A conversion table was prepared to allow the pooling of the results over different revisions of the International Classification of Diseases (ICD) ${ }^{29-31}$

National incidence reference rates, all according to the 7th ICD revision ${ }^{29}$ have been supplied and used for calculating expected incident cancer cases. This applies to the four Nordic countries (Denmark, Finland, Norway, and Sweden) providing cancer registration at national level.

Table 2 No of subjects in the database, No of exclusions, and final No in the analysis

\begin{tabular}{|c|c|c|c|c|c|c|c|c|c|c|}
\hline & \multirow[b]{2}{*}{$\begin{array}{l}\text { No of } \\
\text { subjects } \\
\text { in the } \\
\text { database }\end{array}$} & \multicolumn{7}{|c|}{ No of subjects excluded due to: } & \multirow[b]{2}{*}{$\begin{array}{l}\text { Total No of } \\
\text { subjects } \\
\text { excluded } \\
\text { from } \\
\text { analysis }\end{array}$} & \multirow[b]{2}{*}{$\begin{array}{l}\text { Total } \\
\text { of subfe } \\
\text { in the } \\
\text { analyst }\end{array}$} \\
\hline & & $\begin{array}{l}\text { Date of } \\
\text { birth } \\
\text { unknown }\end{array}$ & $\begin{array}{l}\text { Date of } \\
\text { exit } \\
\text { unknown }\end{array}$ & $\begin{array}{l}\text { Date of } \\
\text { first } \\
\text { exposure } \\
\text { unknown }\end{array}$ & $\begin{array}{l}\text { Exit before } \\
\text { observation } \\
\text { period } \\
\text { started }\end{array}$ & $\begin{array}{l}\text { Specific } \\
\text { problems }\end{array}$ & $\begin{array}{l}\text { Not } \\
\text { satisfying } \\
\text { inclusion } \\
\text { criteria }\end{array}$ & $\begin{array}{l}\text { Factories } \\
\text { excluded }\end{array}$ & & \\
\hline Denmark & 5357 & - & 3 & 54 & 8 & 8 & 412 & 230 & 715 & $4642 \bar{D}$ \\
\hline England & 398 & 1 & 1 & 2 & 1 & - & - & - & 5 & 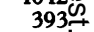 \\
\hline Finland & 1950 & - & - & - & 19 & - & 123 & - & 142 & 1808 \\
\hline France & 1272 & - & 1 & - & - & 1 & 80 & - & 82 & $1190=$ \\
\hline Germany & 1221 & - & - & - & 15 & - & 7 & - & 22 & 1199움 \\
\hline Italy & 460 & - & - & - & 13 & - & - & - & 13 & 447 D \\
\hline Norway & 783 & - & - & - & 1 & - & 45 & - & 46 & $737 \frac{\Omega}{\Phi}$ \\
\hline Scotland & 239 & 1 & 1 & 一 & - & - & - & - & 2 & 237อ \\
\hline Sweden & 439 & - & - & $\overline{-}$ & $\overline{-}$ & - & - & $\overline{-}$ & - & ${ }^{439} \sigma$ \\
\hline Total cohort & 12119 & 2 & 6 & 56 & 57 & 9 & 667 & 230 & 1027 & $11092<$ \\
\hline
\end{tabular}


Table 3 No of subjects by country and vital state

\begin{tabular}{|c|c|c|c|c|c|c|c|c|c|c|}
\hline \multirow[b]{3}{*}{$\begin{array}{l}\text { Total } \\
\text { Denmark } \\
\text { England } \\
\text { Finland } \\
\text { France } \\
\text { Germany } \\
\text { Italy } \\
\text { Norway } \\
\text { Scotland } \\
\text { Sweden }\end{array}$} & \multirow{2}{*}{\multicolumn{2}{|c|}{$\frac{\text { Total }}{\text { Total }(\%)}$}} & \multirow{2}{*}{\multicolumn{2}{|c|}{$\frac{\text { Alive }}{\text { Total (\%) }}$}} & \multirow{2}{*}{\multicolumn{2}{|c|}{$\frac{\text { Dead }}{\text { Total }(\%)}$}} & \multirow{2}{*}{\multicolumn{2}{|c|}{$\frac{\text { Lost to follow up }}{\text { Total (\%) }}$}} & \multirow{2}{*}{\multicolumn{2}{|c|}{$\frac{\text { Emigrated }}{\text { Total (\%) }}$}} \\
\hline & & & & & & & & & & \\
\hline & $\begin{array}{r}11092 \\
4642 \\
393 \\
1808 \\
1190 \\
1199 \\
447 \\
737 \\
237 \\
439\end{array}$ & $\begin{array}{l}(100 \cdot 00) \\
(100 \cdot 00) \\
(100 \cdot 00) \\
(100 \cdot 00) \\
(100 \cdot 00) \\
(100 \cdot 00) \\
(100 \cdot 00) \\
(100 \cdot 00) \\
(100 \cdot 00) \\
(100 \cdot 00)\end{array}$ & \begin{tabular}{r|}
9661 \\
4361 \\
317 \\
1224 \\
1093 \\
1123 \\
399 \\
646 \\
145 \\
353
\end{tabular} & $\begin{array}{l}(87.10) \\
(93.95) \\
(80.66) \\
(67.70) \\
(91.85) \\
(93.66) \\
(89.26) \\
(87.65) \\
(61.18) \\
(80.41)\end{array}$ & $\begin{array}{r}1093 \\
230 \\
55 \\
468 \\
53 \\
62 \\
26 \\
66 \\
47 \\
86\end{array}$ & $\begin{array}{r}(9.85) \\
(4.95) \\
(13.99) \\
(25.88) \\
(4.45) \\
(5.17) \\
(5.82) \\
(8.96) \\
(19.83) \\
(19.59)\end{array}$ & $\begin{array}{r}137 \\
2 \\
21 \\
44 \\
8 \\
21 \\
1 \\
40 \\
-\end{array}$ & $\begin{array}{c}(1.24) \\
(0.04) \\
(5.34) \\
(-) \\
(3.70) \\
(0.67) \\
(4.70) \\
(0.14) \\
(16.88) \\
(-)\end{array}$ & $\begin{array}{r}201 \\
49 \\
116 \\
6 \\
1 \\
24 \\
5 \\
\end{array}$ & $\begin{array}{c}(1.81) \\
(1.06) \\
(-) \\
(6.42) \\
(-) \\
(0.50) \\
(0.22) \\
(3.26) \\
(2 \cdot 11) \\
(-)\end{array}$ \\
\hline
\end{tabular}

Data processing and quality control were centrally performed at IARC in close collaboration with the national investigators. The expected number of deaths or incident cases were computed by multiplying the accumulated person-years in each stratum across age and calendar period by the national reference rates. $^{32}$ Standardised mortality ratios (SMRs) and standardised incidence ratios (SIRs) were calculated as the ratio of observed to expected multiplied by 100 . Ninety five per cent confidence intervals (95\% CIs) for SMRs and SIRs were computed assuming a Poisson distribution.

For analysis by both qualitative and quantitative fume exposure categories, subjects needed to be included in categories by type of metal (mild or stainless steel in most cases) or welding process (MIG, MAG, TIG, or MMA in most cases). For most of the cohort these data were available at individual levels, but most subjects were assigned to these exposure groups based on a systematic history of each plant. Shipyard workers were separated from mild steel workers in factories, because it was judged that exposure to asbestos was likely to have been higher in shipyards. Because exposures to $\mathrm{Cr}$ and $\mathrm{Ni}$ are much higher in stainless steel than in mild steel welding, the factory welders were categorised as either mild steel only or stainless steel ever. A subgroup of stainless steel welders, "predominantly stainless steel," was also considered. This consisted of subjects who had had at least one occupational period welding stainless steel only or were employed in a company with at least $70 \%$ of stainless steel activity (for Sweden the pre-existing criterion of inclusion was at least $50 \%$ employment in stainless steel welding).

For each subject employed for at least five years as a welder a cumulative dose was computed on the basis of estimated levels of exposure specific to type of metal welded, and factory and technological changes over time. This was calculated using an algorithm based on the history of welding in the plants or companies as well as the available individual information. Boundaries have been chosen on the basis of the cumulated exposure at the threshold limit values recommended by the American Conference of Governmental Industrial Hygienists ${ }^{33}$ after one, five, 10,15 , and 20 or more years of employment and taking into account as far as possible an even distribution of the expected numbers in each category.

The estimated plant specific levels of exposure to total fumes (TF), total $\mathrm{Cr}$, hexavalent $\mathrm{Cr}$ (Cr VI), and $\mathrm{Ni}$ were prepared before the statistical analysis by two of us (CG and MG). The methodology is described in detail elsewhere. ${ }^{34} 35$

Other exposures could not be estimated due to the low quality of the information in the case of asbestos, or to the lack of information in the cases of $\alpha$ radiation (from the use of thorium in TIG welding) and electromagnetic fields.

Table 4 No in cohort and person-years by time since first exposure: total cohort

\begin{tabular}{|c|c|c|c|c|c|}
\hline \multirow[b]{2}{*}{ Country } & \multicolumn{4}{|c|}{ Years since first exposure } & \multirow[b]{2}{*}{ Total } \\
\hline & $0-9$ & $10-19$ & $20-29$ & $\geqslant 30$ & \\
\hline \multicolumn{6}{|c|}{ No in cohort } \\
\hline $\begin{array}{l}\text { Denmark } \\
\text { England } \\
\text { Finland } \\
\text { France } \\
\text { Germany } \\
\text { Italy } \\
\text { Norway } \\
\text { Scotland } \\
\text { Sweden } \\
\text { Total }\end{array}$ & $\begin{array}{r}4421 \\
370 \\
1619 \\
819 \\
841 \\
335 \\
737 \\
123 \\
368 \\
9633\end{array}$ & $\begin{array}{r}2771 \\
337 \\
1763 \\
910 \\
1156 \\
355 \\
705 \\
186 \\
436 \\
8619\end{array}$ & $\begin{array}{r}988 \\
195 \\
1620 \\
409 \\
499 \\
134 \\
256 \\
155 \\
426 \\
4682\end{array}$ & $\begin{array}{r}112 \\
86 \\
1162 \\
146 \\
94 \\
34 \\
86 \\
72 \\
304 \\
2096\end{array}$ & $\begin{array}{r}4642 \\
393 \\
1808 \\
1190 \\
1199 \\
447 \\
737 \\
237 \\
439 \\
11092\end{array}$ \\
\hline \multicolumn{6}{|c|}{ Person-years } \\
\hline $\begin{array}{l}\text { Denmark } \\
\text { England } \\
\text { Finland } \\
\text { France } \\
\text { Germany } \\
\text { Italy } \\
\text { Norway } \\
\text { Scotland } \\
\text { Sweden } \\
\text { Total }\end{array}$ & $\begin{array}{r}28510 \\
1632 \\
10320 \\
4743 \\
5545 \\
2628 \\
6670 \\
475 \\
1700 \\
62223\end{array}$ & $\begin{array}{r}17466 \\
2575 \\
16269 \\
4862 \\
6369 \\
1659 \\
4608 \\
1288 \\
4004 \\
59099\end{array}$ & $\begin{array}{r}3077 \\
1292 \\
14736 \\
2038 \\
2483 \\
737 \\
1694 \\
947 \\
3906 \\
30910\end{array}$ & $\begin{array}{r}670 \\
539 \\
6990 \\
650 \\
37 \\
161 \\
427 \\
515 \\
1857 \\
11845\end{array}$ & $\begin{array}{r}49722 \\
6038 \\
48315 \\
12293 \\
14434 \\
5185 \\
13399 \\
3225 \\
11467 \\
164077\end{array}$ \\
\hline
\end{tabular}


Table 5 Mortality by detailed cause: total cohort

\begin{tabular}{|c|c|c|c|c|}
\hline Cause of death (ICD 8th rev) & Obs & $\operatorname{Exp}$ & \multicolumn{2}{|c|}{$S M R(95 \% C I)$} \\
\hline All causes (000-999) & 1093 & $1179 \cdot 08$ & 93 & $(87-98)$ \\
\hline $\begin{array}{l}\text { All malignant neoplasms (140-207): } \\
\text { Buccal cavity and pharynx (140-149) } \\
\text { Oesophagus (150) } \\
\text { Stomach (151) } \\
\text { Intestine except rectum (152-153) } \\
\text { Rectum (154) } \\
\text { Nose and nasal cavities (160) } \\
\text { Larynx (161) } \\
\text { Trachea, bronchus, and lung (162) } \\
\text { Prostate (185) } \\
\text { Bladder (188) } \\
\text { Kidney (189) } \\
\text { Lymphosarcoma (200) } \\
\text { Hodgkin's disease (201) } \\
\text { Leukaemia (204-207) } \\
\text { Other lymphatic neoplasms (202-203) } \\
\text { Other malignant neoplasms }\end{array}$ & $\begin{array}{r}303 \\
3 \\
4 \\
26 \\
17 \\
7 \\
0 \\
7 \\
116 \\
10 \\
15 \\
12 \\
6 \\
2 \\
6 \\
7\end{array}$ & $\begin{array}{r}268 \cdot 63 \\
6 \cdot 79 \\
7 \cdot 07 \\
27 \cdot 14 \\
14 \cdot 41 \\
10 \cdot 28 \\
0 \cdot 83 \\
4 \cdot 74 \\
86 \cdot 81 \\
12 \cdot 95 \\
7 \cdot 86 \\
8 \cdot 61 \\
3 \cdot 52 \\
3 \cdot 32 \\
9 \cdot 49 \\
6 \cdot 12 \\
58 \cdot 72\end{array}$ & $\begin{array}{r}113 \\
44 \\
57 \\
96 \\
118 \\
68 \\
0 \\
148 \\
134 \\
77 \\
191 \\
139 \\
171 \\
60 \\
63 \\
114 \\
111\end{array}$ & $\begin{array}{r}(100-126) \\
(9-129) \\
(15-145) \\
(63-140) \\
(69-189) \\
(27-140) \\
(0-444) \\
(59-304) \\
(110-160) \\
(37-142) \\
(107-315) \\
(72-243) \\
(63-371) \\
(7-218) \\
(23-138) \\
(46-236) \\
(85-141)\end{array}$ \\
\hline Benign and unspecified neoplasms $(210-239,208)$ & 5 & $5 \cdot 08$ & 98 & $(32-230)$ \\
\hline Circulatory system $(390-458)$ & 469 & $499 \cdot 74$ & 94 & $(86-103)$ \\
\hline $\begin{array}{l}\text { Respiratory system (460-519): } \\
\text { Pneumonia (480-486) } \\
\text { Bronchitis, emphysema, and asthma (490-493) } \\
\text { Other respiratory diseases }\end{array}$ & $\begin{array}{r}42 \\
12 \\
26 \\
4\end{array}$ & $\begin{array}{l}60 \cdot 84 \\
19 \cdot 16 \\
30 \cdot 75 \\
10 \cdot 94\end{array}$ & $\begin{array}{l}69 \\
63 \\
85 \\
37\end{array}$ & $\begin{array}{l}(50-93) \\
(32-109) \\
(55-124) \\
(10-94)\end{array}$ \\
\hline Digestive system $(520-577)$ & 34 & $50 \cdot 82$ & 67 & $(46-93)$ \\
\hline $\begin{array}{l}\text { Accidents, poisonings, and violence (E800-E999): } \\
\text { Industrial accidents (E916-E921, E923-E928) } \\
\text { Suicide (E950-E959) } \\
\text { Other violent causes }\end{array}$ & $\begin{array}{r}142 \\
7 \\
44 \\
91\end{array}$ & $\begin{array}{r}183 \cdot 72 \\
8 \cdot 44 \\
66 \cdot 39 \\
108 \cdot 89\end{array}$ & $\begin{array}{l}77 \\
83 \\
66 \\
84\end{array}$ & $\begin{array}{l}(65-91) \\
(33-171) \\
(48-89) \\
(67-103)\end{array}$ \\
\hline Other known causes & 89 & $110 \cdot 25$ & 81 & $(65-99)$ \\
\hline Unknown causes & 9 & & & \\
\hline
\end{tabular}

\section{Mortality results}

Table 4 presents the number of subjects and personyears at risk contributed by time since first exposure for the total cohort and for each of the countries. Each member of the cohort contributed on average 14.8 person-years at risk, ranging from a 10.3 personyears contribution from France to $26 \cdot 7$ person-years from Finland.

Table 5 presents the overall mortality for the total cohort by cause. For all causes a statistically significant deficit is present. This deficit is consistent in all main groups of causes of death apart from malignant neoplasms, which shows an excess of borderline statistical significance. The main contribution to this excess derives from lung cancer (116 observed $v$ 86.81 expected deaths). Other excesses are cancer of the bladder, kidney, and larynx, and lymphosarcoma.

Table 6 gives the mortality for a selected number of causes of death by time since first exposure. There is no clear tendency for risk of lung cancer or any other cancer to increase with increase in time since first exposure.
When mortality from lung cancer is analysed by time since first exposure separately for the four different subcohorts of welders, however (table 7), there is a tendency for the SMR to increase with time since first exposure among mild steel, stainless steel ever, and predominantly stainless steel welders.

The trend to increase with time is more noticeable for predominantly stainless steel welders and is statistically significant for this subcohort only $\left(\chi^{2}=\right.$ 5.03, 1 df; $p<0.05$ ).

The subsequent tables concentrate on the risk of lung cancer, the main focus of interest in this study. Tables 8 to 11 present results for mortality from lung cancer subdivided by time since first exposure and duration of employment for the four subcohorts. Shipyard welders show a slight mortality excess that is limited to the group with less than 20 years since first exposure and is not increased among those with 10 or more years of employment (table 8). A larger mortality excess, which is statistically significant, is present for lung cancer among mild steel welders (table 9). The excess is larger 20 or more years since first employment. This pattern is most apparent 
able 6 Mortality by time since first exposure for selected sites: total cohort

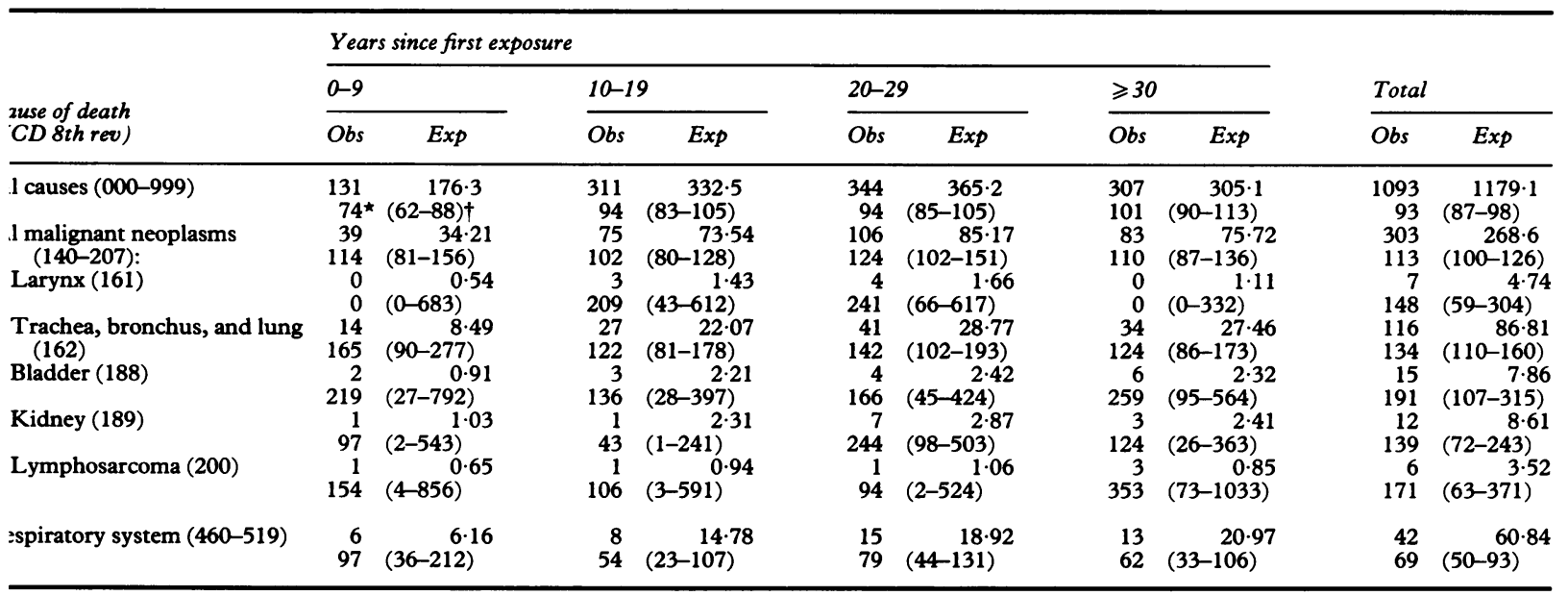

os = Observed deaths; Exp = expected deaths.

iMR.

$5 \%$ CI.

among those with less than 10 years of employment.

Stainless steel ever welders also exhibit a moderate lung cancer excess that is apparent only after 20 years since first employment and does not appear to be associated with duration of employment (table 10).

An excess of the same magnitude is present for the cohort with predominant exposure to stainless steel and shows a more pronounced tendency to increase after 20 years since first exposure than the stainless steel ever cohort. Numbers are small within employment and follow up cells and no clear increase with duration of employment is apparent (table 11).

As outlined in the materials and methods section a dose response investigation of lung cancer mortality has been performed using estimated levels of exposure to $\mathrm{TF}, \mathrm{Cr}, \mathrm{Cr} \mathrm{VI}$, and $\mathrm{Ni}$. No association was found with cumulative doses of TF and total $\mathrm{Cr}$ in any of the four subgroups. Standard mortality ratios for mild steel and predominantly stainless steel welders with at least 10 years of employment and 20 years since first exposure were 173 (15 observed deaths) and 176 (11 observed deaths). These results are not presented here, but are available in detail in the full IARC report of the study. ${ }^{35}$

As a main interest is the possible risk from exposure to $\mathrm{Cr} \mathrm{VI}$ and $\mathrm{Ni}$ among stainless steel welders, the results presented in table 12 are limited to the two subgroups of stainless steel welders with at least 5 years of exposure and concern the analysis of lung cancer mortality in the two subcohorts of stainless steel ever and predominantly stainless steel welders by cumulative estimated doses of $\mathrm{Cr} \mathrm{VI}$ and

able 7 Lung cancer mortality by time since first exposure and by type of welding activity

\begin{tabular}{|c|c|c|c|c|c|c|c|c|c|c|}
\hline \multirow[b]{3}{*}{ ype of welding } & \multicolumn{8}{|c|}{ Years since first exposure } & & \\
\hline & \multicolumn{2}{|l|}{$0-9$} & \multicolumn{2}{|c|}{$10-19$} & \multicolumn{2}{|c|}{$20-29$} & \multicolumn{2}{|c|}{$\geqslant 30$} & \multicolumn{2}{|c|}{ Total } \\
\hline & Obs & $E x p$ & Obs & $E x p$ & Obs & $E x p$ & Obs & $\operatorname{Exp}$ & Obs & $\operatorname{Exp}$ \\
\hline $\begin{array}{l}\text { hipyard welders } \\
\text { lild steel welders } \\
\text { tainless steel ever } \\
\text { welders } \\
\text { redominantly stainless } \\
\text { steel welders }\end{array}$ & $\begin{array}{r}5 \\
508 \star \\
4 \\
135 \\
5 \\
104 \\
2 \\
64\end{array}$ & $\begin{array}{c}0.99 \\
(165-1185) \dagger \\
2 \cdot 97 \\
(37-345) \\
4 \cdot 80 \\
(34-243) \\
3 \cdot 11 \\
(8-232)\end{array}$ & $\begin{array}{r}6 \\
141 \\
11 \\
162 \\
12 \\
107 \\
5 \\
88\end{array}$ & $\begin{array}{c}4 \cdot 27 \\
(52-306) \\
6 \cdot 79 \\
(81-290) \\
11 \cdot 26 \\
(55-186) \\
5 \cdot 67 \\
(29-206)\end{array}$ & $\begin{array}{r}17 \\
161 \\
11 \\
186 \\
13 \\
132 \\
7 \\
126\end{array}$ & $\begin{array}{c}10 \cdot 58 \\
(94-257) \\
5 \cdot 91 \\
(93-333) \\
9 \cdot 83 \\
(70-226) \\
5 \cdot 54 \\
(51-260)\end{array}$ & $\begin{array}{r}8 \\
63 \\
14 \\
207 \\
9 \\
194 \\
6 \\
612\end{array}$ & $\begin{array}{c}12 \cdot 79 \\
(27-123) \\
6 \cdot 75 \\
(113-348) \\
4 \cdot 63 \\
(89-369) \\
1 \cdot 92 \\
(115-679)\end{array}$ & $\begin{array}{r}36 \\
126 \\
40 \\
178 \\
39 \\
128 \\
20 \\
123\end{array}$ & $\begin{array}{c}28 \cdot 62 \\
(88-174) \\
22 \cdot 42 \\
(127-243) \\
30 \cdot 52 \\
(91-175) \\
16 \cdot 25 \\
(75-190)\end{array}$ \\
\hline
\end{tabular}

bs = Observed deaths; Exp = expected deaths.

SMR.

$35 \% \mathrm{CI}$. 
Table 8 Mortality from cancers of trachea, bronchus, and lung by duration of employment and follow up: shipyard welders

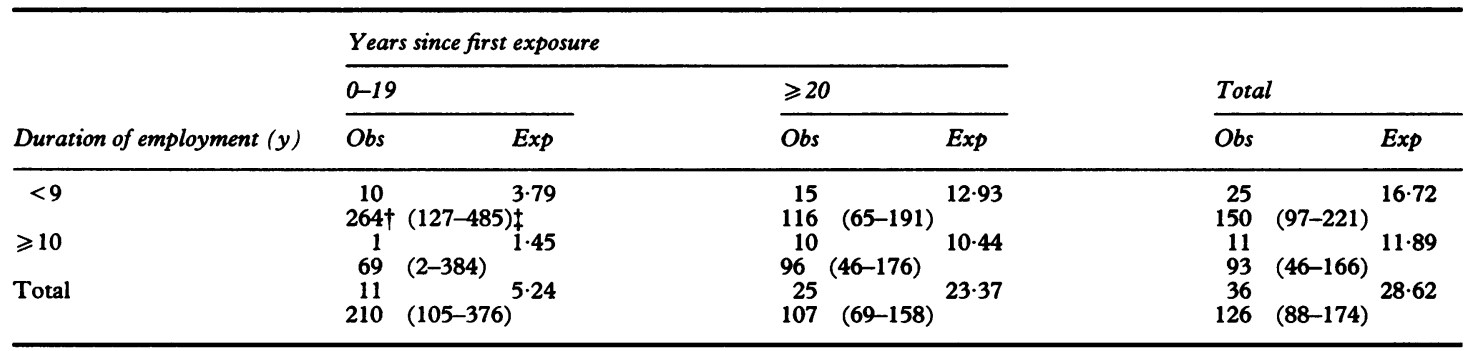

Obs = Observed deaths; Exp = expected deaths.

*ICD 8th rev 162 .

tSMR.

$\$ 95 \%$ CI.

$\mathrm{Ni}$ after 20 years since first exposure. The SMR of 170 in the high Cr VI exposure category is raised compared with the SMR of 123 in the low category, but the difference is not significant. Otherwise no relation between lung cancer and cumulative exposure is apparent. Five deaths from pleural mesothelioma have been identified in the cohort and table 13 reports some individual characteristics of these subjects (we know of one more death in the stainless steel welder group that occurred after the formal end of the follow up and is therefore not included in the analysis). Three of the deaths occurred at least 20 years after first exposure and they belong one each to the subgroups of shipyard welders, mild steel welders, and stainless steel welders. Although expected numbers were not formally computed, we estimate the number of mesothelioma deaths expected in this cohort to be below one on the basis of the general population.

Analysis by cumulative dose was also performed for non-malignant respiratory diseases and we found no association with type of welding or dose (results not presented).

\section{Incidence results}

Cancer incidence analysis was performed on the population of 7510 welders ( $68 \%$ of the total cohort) from the four Nordic countries that contributed 98376 person-years $(60 \%$ of the total).

The results for a number of selected sites (table 14) confirm the lung cancer excess and also suggest an increased SIR for prostate cancer. Neither of those sites, when further analysed, showed any association with exposure. In particular, no difference exists for lung cancer between stainless steel ever and predominantly stainless steel welders in relation to cumulative exposure to $\mathrm{Cr} \mathrm{VI}$ and $\mathrm{Ni}$ (the results are not presented here). An excess for cancer of the buccal cavity and pharynx is also indicated but it was not statistically significant.

\section{Discussion}

The population of welders investigated in this collaborative study is characterised by a large heterogeneity of exposure due to the different metals welded, different technologies used, different types of industrial production, and the different criteria of inclusion that have been adopted in the various countries.

The mortality from all causes and from the main groups of causes of deaths, with the exception of

Table 9 Mortality from cancers of trachea, bronchus, and lung ${ }^{\star}$ by duration of employment and follow up: mild steel welders

\begin{tabular}{|c|c|c|c|c|c|c|c|}
\hline \multirow[b]{3}{*}{ Duration of employment (y) } & \multicolumn{4}{|c|}{ Years since first exposure } & & & \\
\hline & \multicolumn{2}{|l|}{$0-19$} & \multicolumn{2}{|c|}{$\geqslant 20$} & \multicolumn{3}{|c|}{ Total } \\
\hline & Obs & $\operatorname{Exp}$ & Obs & $\operatorname{Exp}$ & Obs & & $\operatorname{Exp}$ \\
\hline $\begin{array}{c}<9 \\
\geqslant 10 \\
\text { Total }\end{array}$ & $\begin{array}{c}8 \\
116 \dagger \\
7 \\
253 \\
15 \\
155\end{array}$ & $\begin{array}{l}(50-228) \ddagger^{6.92} \\
2 \cdot 77 \\
(102-521) \\
(87-255)\end{array}$ & $\begin{array}{r}10 \\
254 \\
15 \\
173 \\
25 \\
198\end{array}$ & $\begin{array}{l}(122-467)^{3.94} \\
(9.68-285){ }^{12.62} \\
(128-292)^{12.0}\end{array}$ & $\begin{array}{r}18 \\
166 \\
22 \\
192 \\
40 \\
179\end{array}$ & $\begin{array}{l}(98-262) \\
(120-291) \\
(128-244)\end{array}$ & $\begin{array}{l}10 \cdot 86 \\
11 \cdot 45 \\
22 \cdot 31\end{array}$ \\
\hline
\end{tabular}

See footnotes, table 8 for explanations. 
Table 10 Mortality from cancers of trachea, bronchus, and lung by duration of employment and follow up: stainless steel ever welders

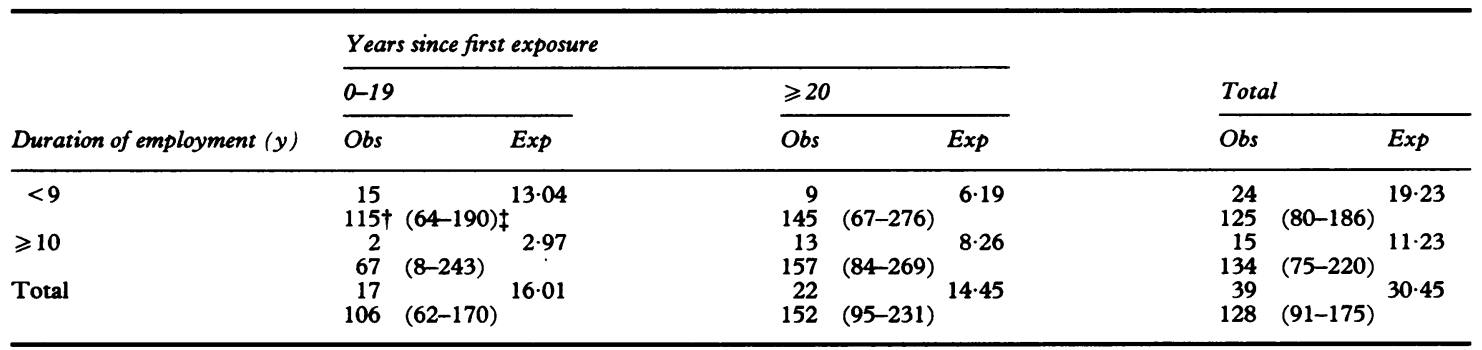

See footnotes, table 8 for explanations.

malignant neoplasms, is lower than that of the general population. This deficit is almost entirely due to the low mortality of stainless steel welders, and no such pattern is discernible among mild steel welders and shipyard welders. The deficit is particularly noticeable for deaths from non-malignant respiratory diseases and again it is more evident among stainless steel welders than among mild steel and shipyard welders. This "healthy worker effect" may be related to stainless steel welding being a more highly qualified and better remunerated job than the other types of welding considered here. In some countries (for instance, Germany) a special training followed by an official examination is required to become a stainless steel welder.

The low mortality from respiratory disease for stainless steel welders is remarkable given that stainless steel welding fumes irritate the mucous membranes and have also been reported to cause allergic asthma ${ }^{36}$ This might have led to a secondary selection particularly when long term employees are analysed.

Among the main groups of causes only mortality from malignant neoplasms presents an excess that is of borderline statistical significance. Several cancers are in excess that have not been reported before-for instance, bladder cancer (statistically significant), and lymphosarcoma. These sites do not appear to be related to time since first exposure, nor to duration of employment.

An increased incidence of prostate cancer is concentrated among shipyard and mild steel welders and does not appear to be related to exposure.

Hodgkin's disease and leukaemia, which have been reported in excess in some studies, did not show an excess overall. Cancer of the kidney, although in excess, did not show any relation with exposure.

Based on previous evidence in man and on the information available on exposure, cancers of the nose, larynx, and lung were a priori considered the sites at increased risk. No death from nasal cancer was recorded among the members of the cohort but less than one death was expected. The overall mortality excess from cancer of the larynx is based on insufficient numbers to allow an analysis by time since first exposure, duration, or estimated cumulative exposure.

The investigation of the risk of lung cancer among welders was the main purpose of this collaborative effort. The study was large enough to have an $80 \%$

Table 11 Mortality from cancers of trachea, bronchus, and lung by duration of employment and follow up: predominantly stainless steel welders

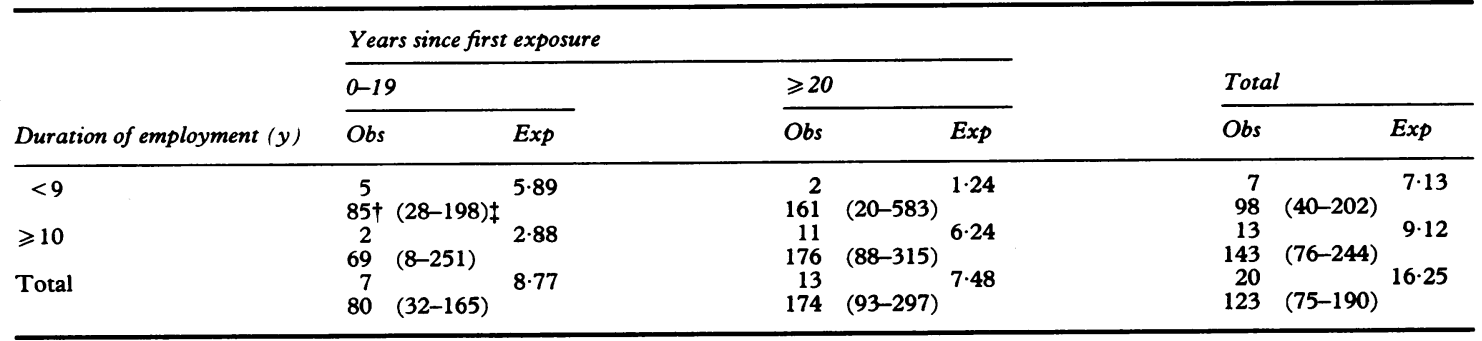

See footnotes, table 8 for explanations. 
Table 12 Lung cancer mortality for welders with at least five years of employment by subgroup and cumulative exposure after 20 years since first exposure

\begin{tabular}{|c|c|c|c|c|}
\hline & \multicolumn{4}{|c|}{ Cumulative exposure (mg-years $/ m^{3}$ ) } \\
\hline & \multicolumn{2}{|c|}{$<0.5$} & \multicolumn{2}{|c|}{$\geqslant 0.5$} \\
\hline & Obs & $\operatorname{Exp}$ & Obs & $\operatorname{Exp}$ \\
\hline \multicolumn{5}{|c|}{ Stainless steel ever welders } \\
\hline Cr VI & $\begin{array}{c}7 \\
123^{\star} \\
17 \\
166\end{array}$ & $\begin{array}{c}5 \cdot 68 \\
(50-254) \dagger \\
10 \cdot 23 \\
(97-266)\end{array}$ & $\begin{array}{r}14 \\
170 \\
4 \\
109\end{array}$ & $\begin{array}{c}8 \cdot 22 \\
(93-286) \\
3 \cdot 67 \\
(30-279)\end{array}$ \\
\hline \multicolumn{5}{|c|}{ Predominantly stainless steel welders } \\
\hline $\begin{array}{l}\mathrm{Cr} \text { VI } \\
\mathrm{Ni}\end{array}$ & $\begin{array}{r}3 \\
191 \\
8 \\
234\end{array}$ & $\begin{array}{c}1.57 \\
(39-558) \\
3 \cdot 42 \\
(101-461)\end{array}$ & $\begin{array}{r}9 \\
167 \\
4 \\
113\end{array}$ & $\begin{array}{c}5 \cdot 38 \\
(77-318) \\
3 \cdot 53 \\
(31-290)\end{array}$ \\
\hline
\end{tabular}

*SMR.

$+95 \%$ CI.

probability of detecting a $30 \%$ overall increase in the population at risk and a $35 \%$ increase after 20 years since first exposure. The overall mortality excess from lung cancer, although statistically significant, is not associated with duration of exposure when the total cohort is analysed.

Separate analyses of shipyard welders, mild steel welders, stainless steel ever welders, and predominantly stainless steel welders show different patterns of mortality from lung cancer with time since first exposure. The raised lung cancer mortality in the early latency period among shipyard and mild steel welders is diffiicult to explain and could be caused by exposure to carcinogens during previous occupations (this might be particularly so for asbestos exposure among shipyard welders in previous periods of employment at other shipyards).

Mild steel, stainless steel ever, and predominantly stainless steel welders all show an excess after 20 years since first exposure. The excess of observed over expected deaths is greater for mild steel than stainless steel welders. The excess mortality among long observation employees (at least 20 years), however, in mild steel welding is only slightly greater than those with less than 20 years since first employment. The largest difference (more than a twofold increase) between long and short observation groups is present for predominantly stainless steel welders suggesting a relation of lung cancer mortality with the occupational environment for this group. The association, however, is not supported by the analysis of estimated cumulative exposures to TF, $\mathrm{Cr}, \mathrm{Cr}$ VI, and Ni.

These results, overall, are consistent with the findings of three previous studies that indicate an association between lung cancer and stainless steel welding. ${ }^{7818}$

Considering that the cumulative dose for a proportion of the cohort was not based on individual occupational histories but on company information, it is likely that some degree of misclassification has been introduced. This usually has a diluting effect and tends to obscure any dose response relation.

No systematic information is available on previous occupational exposures and therefore the potential confounding effect of previous exposures to occupational carcinogens cannot be ruled out. This could of course include past stainless steel welding experience among workers categorised as mild steel welders in this study.

It has not been possible to evaluate the part played by exposure to asbestos on the excess mortality from lung cancer as the information available from the company histories on exposure to asbestos was too poor to be used in the analysis. Contamination of the working environment from asbestos occurs frequently in shipyards and also in other welding operations. The use of asbestos protection devices (blankets, aprons, gloves, etc) may extend the risk of exposure to this well known carcinogen to the working environment of mild steel and stainless steel welders. That this study population has experienced some past exposure to asbestos can be inferred from the five deaths from pleural mesothelioma. The distribution of the mesothelioma deaths in all the occupational subgroups suggests that the risk of exposure to asbestos might have been widespread in all welding operations, or that some welders in each particular category have worked in past jobs with significant exposure to asbestos.

Table 13 Information on mesothelioma deaths observed in the cohort

\begin{tabular}{lllll}
\hline & $\begin{array}{l}\text { Age at } \\
\text { death }(y)\end{array}$ & $\begin{array}{l}\text { Time since } \\
\text { first } \\
\text { exposure }(y)\end{array}$ & $\begin{array}{l}\text { Duration } \\
\text { group }(y)\end{array}$ & Exposure group \\
\hline Deuntry & 74 & 21 & $15-20$ & Mild steel only \\
Denmark & 63 & 9 & $1-5$ & Mild steel only \\
Finland & 50 & 26 & $1-5$ & Shipyard (mild steel only) \\
Germany & 50 & 17 & $10-15$ & Stainless steel ever \\
Scotland & 68 & 28 & $>20$ & Stainless steel ever \\
& & 20 & $1-5$ & Total welding activity \\
& & & & Stainless steel
\end{tabular}


Table 14 Incidence of cancer by detailed site; cohort subjects from Denmark, Finland, Norway, and Sweden

\begin{tabular}{|c|c|c|c|}
\hline Cancer site (ICD 7th rev) & Obs & $E x p$ & $\operatorname{SIR}(95 \% C I)$ \\
\hline $\begin{array}{l}\text { All malignant neoplasms } \\
\text { (140-205): } \\
\text { Buccal cavity and pharynx } \\
(140-148) \\
\text { Oesophagus (150) } \\
\text { Stomach (151) } \\
\text { Intestine, except rectum } \\
\text { (152-153) } \\
\text { Rectum (154) } \\
\text { Larynx (161) } \\
\text { Trachea, bronchus, and lung } \\
\text { (162-163) } \\
\text { Prostate (177) } \\
\text { Bladder (181) } \\
\text { Leukaemia (204) } \\
\text { Other lymphatic neoplasms } \\
\text { (200-203, 205) } \\
\text { Other malignant neoplasms }\end{array}$ & $\begin{array}{r}14 \\
5 \\
92 \\
36 \\
22 \\
11 \\
15 \\
107\end{array}$ & $\begin{array}{r}11 \cdot 23 \\
3 \cdot 57 \\
21 \cdot 23 \\
\\
16 \cdot 95 \\
13 \cdot 10 \\
6 \cdot 30 \\
\\
67 \cdot 02 \\
24 \cdot 70 \\
18 \cdot 15 \\
8 \cdot 76\end{array}$ & $\begin{aligned} 120 & (108-133) \\
160 & (95-253) \\
56 & (7-202) \\
85 & (50-134) \\
& \\
136 & (86-204) \\
107 & (58-179) \\
79 & (26-185) \\
137 & (111-168) \\
146 & (102-202) \\
121 & (76-184) \\
126 & (63-225) \\
112 & (63-185) \\
110 & (90-133)\end{aligned}$ \\
\hline
\end{tabular}

The prevalence of smoking can be higher for industrial populations when compared with the general population and such differences might explain, at least in part, the difference in mortality from lung cancer. The overall lung cancer excess in this cohort falls into the range, albeit at the upper limit, which could be explained by the confounding effect of tobacco smoking, and the excess from bladder cancer is consistent with this hypothesis.

As previously mentioned, information on smoking habits is not available for the entire cohort so no adjustment for tobacco could be performed. For two of the national subcohorts, however (Finland and Norway), smoking habits collected through surveys do not indicate a substantial difference between the members of the cohort and the general population. Furthermore, the low mortality from diseases of the cardiovascular and respiratory systems, and the magnitude of the excess after 20 years since first exposure do not support the hypothesis of tobacco smoke as the main explanation of the lung cancer excess.

\section{Conclusions}

The historical follow up of this heterogeneous cohort of welders showed no overall mortality excess apart from a significant increase in mortality from all malignant neoplasms, mainly due to an increased mortality from lung cancer.

The excess mortality from lung cancer is present among shipyard welders, mild steel welders, and stainless steel welders but it does not appear to be related to duration of employment or cumulative exposure to $\mathrm{TF}$, total $\mathrm{Cr}, \mathrm{Cr} \mathrm{VI}$, or $\mathrm{Ni}$.

The mortality from lung cancer after 20 years since first exposure in the workplaces under study is approximately doubled for both mild steel welders and those predominantly engaged in stainless steel welding. Among stainless steel welders the lung cancer excess is limited to workers with at least 20 years since first exposure and it is greater among predominantly stainless steel welders than among stainless steel ever welders. Overall, these data suggest a possible role of occupational exposure to stainless steel welding fumes in the excess mortality from lung cancer. Although the patterns of mortality from lung cancer suggest that the lung cancer risk is higher for stainless steel than for mild steel welders we cannot quantify with precision the different level of risk for these two categories of welding exposure.

The potential confounding effect of smoking could not be ruled out in this historical study and tobacco could certainly have contributed to the overall excess, although partial data from some of the countries do not indicate heavier smoking habits among welders compared with the general population. The excess is, however, unlikely to be explained by different smoking habits between the study population and the reference populations.

The finding of five mesotheliomas and the distribution of the five deaths from this tumour strongly suggest that past exposure to asbestos affects welders inside and outside shipyards. Asbestos exposure might therefore have contributed to the excess lung cancer.

No excess from non-malignant respiratory diseases was present in this cohort.

The Commission of European Communities, DGV, has partially supported the study. We thank Dr G Aresini, DGV, for his constant interest in the study. We are also indebted to Dr R Stern, WHO/EURO and to Dr E Beck-Hansen, Danish Welding Institute, for their invaluable help.

\section{Appendix}

NAMES, CENTRES, AND COUNTRIES OF MEMBERS OF THE WORKING GROUP

L Simonato, Regional Center for Oncology, Cancer Registry, ULSS 21-Padova, Italy (Unit of Analytical Epidemiology IARC until 31 December 1988).

A C Fletcher, Institute of Occupational Health, University of Birmingham, UK (Unit of Analytical Epidemiology, IARC until 31 December 1987).

A Andersen, The Cancer Registry of Norway, Oslo, Norway.

K Anderson, Institute of Cancer Research, Sutton, UK.

N Becker, Institute of Epidemiology and Biometrics, Germany.

J Chang-Claude, Institute of Epidemiology and Biometrics, Germany. 
G Ferro, Unit of Analytical Epidemiology, IARC, France.

M Gérin, Département de Médecine du Travail, Université de Montréal, Canada.

C N Gray, Institute of Occupational Health, University of Birmingham, UK.

K S Hansen, Institute of Community Medicine, Odense University, Odense, Denmark.

P-L Kalliomäki, Institute of Occupational Health, Helsinki, Finland.

$\mathrm{K}$ Kurppa, Institute of Occupational Health, Helsinki, Finland.

S Långard, Telemark Central Hospital, Porsgrunn, Norway.

F Merló, National Institute for Research on Cancer, Genova, Italy.

J J Moulin, French National Institute of Research and Safety (INRS), 54500 Vandoeuvre-lesNancy, France.

M L Newhouse, TUC Centenary Institute of Occupational Health, London School of Hygiene and Tropical Medicine, London, UK.

J Peto, Institute of Cancer Research, Sutton, UK.

E Pukkala, Finnish Cancer Registry, Helsinki, Finland.

R Saracci, Unit of Analytical Epidemiology, IARC, France.

B Sjögren, National Institute of Occupational Health, Stockholm, Sweden.

$P$ Wild, French National Institute of Research and Safety (INRS), 54500 Vandoeuvre-les-Nancy, France.

R Winkelmann, Unit of Analytical Epidemiology, IARC, France.

1 Breslow L, Hoaglin L, Rasmussen G, Abrams HK. Occupations and cigarette smoking as factors in lung cancer. Am J Public Health 1954;44:171-81.

2 Howe GR, Chambers L, Gordon P, Morrison B, Miller AB. An epidemiological study of bladder cancer. Am J Epidemiol 1977;106:239-46.

3 Decoufle P, Stanislawczyk K, Houten L, Bross IDJ, Viadana E. Retrospective survey of cancer in relation to occupation. Cincinnati: US Department of Health Education and Welfare, National Institute for Occupational Safety and Health, 1978. (DHEW (NIOSH) publ No 77-178.)

4 Blot WJ, Harrington JM, Toledo A, Hoover R, Heath CW, Fraumeni JF. Lung cancer after employment in shipyards in World War II. New England Journal of Medicine 1978;299: 620-4.

5 Blot WJ, Morris LE, Stroube R, Tagnon I, Fraumeni JF. Lung and laryngeal cancers in relation to shipyard employment in coastal Virginia. J Natl Cancer Inst 1980;65:571-5.

6 Gottlieb M. Lung cancer and the petroleum industry in Louisiana. J Occup Med 1980;22:384-8.

7 Gérin M, Siemiatycki J, Richardson L, Pellerin J, Lakhani R, Dewar $R$. Nickel and cancer associations from a multicancer occupation exposure case-referent study: preliminary findings. In: Sunderman FW, ed. Nickel in the human environment. Lyon: International Agency for Research on Cancer, 1984: 105-15. (Sci publ No 53.)

8 Kjuus $H$, Skjaerven R, Längard S, Lien JT, Aamondt T. A case referent study of lung cancer, occupational exposures and smoking: Scand J Work Environ Health 1986;12:193-202.

9 Rinsky RA, Melius JM, Hornung W, et al. Case-control study of lung cancer in civilian employees at the Portsmouth Naval Shipyard, Kittery, Maine. Am J Epidemiol 1988;127:55-64.

10 Benhamou S, Benhamou E, Flamant R. Occupational risk factors of lung cancer in a French case-control study. Br J Ind
Med 1988;45:231-3.

11 Preston-Martin S, Peters JM. Prior employment as a welder associated with the development of chronic myeloid leukaemia. Br J Cancer 1988;58:105-8.

12 Lerchen ML, Wiggins CL, Samet JM. Lung cancer and occupation in New Mexico. J Natl Cancer Inst 1987;79: 639-45.

13 Dunn JE, Weir JM. A prospective study of mortality of several occupational groups: special emphasis on lung cancer. Arch Environ Health 1968;17:71-6.

14 Ott M, Holder BB, Langner RR. Determinants of mortality in an industrial population. J Occup Med 1976;18:171-7.

15 Puntoni R, Vercelli M, Merlo F, Valerio F, Santi L. Mortality among shipyard workers in Genoa, Italy. Ann N Y Acad Sci 1979;330:353-77.

16 Redmond CK, Wieand HS, Rockette HE. Long term mortality experience of steelworkers. Update for National Institute for Occupational Safety and Health, 1979. (Contract No HSM 1979;99:71:32.)

17 Sjögren B. A retrospective cohort study of mortality among stainless steel welders. Scand J Work Environ Health 1980; 6:197-200

18 Sjögren B, Gustavsson A, Hedstrom L. Mortality in two cohorts of welders exposed to high and low levels of hexavalent chromium. Scand J Work Environ Health 1987;13:247-51.

19 Sheers G, Coles RM. Mesothelioma risks in a naval dockyard. Arch Environ Health 1980;35:276-82.

20 Beaumont JJ, Weiss NS. Lung cancer among welders. J Occup Med 1981;23:839-44.

21 Polednak AP. Mortality among welders, including a group exposed to nickel oxides. Arch Environ Health 1981;36: 235-42.

22 Becker N, Claude J, Frentzel-Beyme R. Cancer risk of arc welders exposed to fumes containing chromium and nickel. Scand J Work Environ Health 1985;11:75-82.

23 Merlo F, Costantini M, Doria M. Cause specific mortality among workers exposed to welding fumes and gases: a historical prospective study. Journal of the University of Environmental and Occupational Health 1989;11:302-16.

24 Tola S, Kalliomäki PL, Pukkala E, Asp S, Korkala ML. Incidence of cancer among welders, platers, machinists, and pipe fitters in shipyards and machine shops. Br J Ind Med 1988;45:209-18.

25 Peto J. Cancer morbidity and mortality studies of welders. In: Stern RM, Berlin A, Fletcher AC, Järvisalo J. Health Hazards and Biological Effects of Welding Fumes and Gases 1986: 423-32. (International Congress Series 676, Excerpta Medica.)

26 International Agency for Research on Cancer. Monographs on the evaluation of carcinogenic risk of chemicals to humans. Vol 49. Chromium, nickel and welding fumes. Lyon: IARC, 1990.

27 Simonato L, Fletcher AC, Saracci R, Thomas TL, eds. Occupational exposure to silica and cancer risk. Lyon: International Agency for Research on Cancer, 1990. (Sci publ No 97.)

28 Stern RM, Berlin A, Fletcher AC, Järvisalo J. Health hazards and biological effects of welding fumes and gases, 1986. (International Congress Series 676, Excerpta Medica.)

29 World Health Organisation. Manual of the international statistical classification of diseases, injuries, and causes of death. (7th revision conference) Geneva: WHO, 1957.

30 World Health Organisation. Manual of the international statistical classification of diseases, injuries, and causes of death. (8th revision conference) Geneva: WHO, 1967.

31 World Health Organisation. Manual of the international statistical classification of diseases, injuries, and causes of death. (9th revision conference) Geneva: WHO, 1978.

32 Coleman M, Douglas A, Hermon C, Peto J. Cohort study analysis with a fortran computer program. Int J Epidemiol 1986;15:134-7.

33 American Conference of Governmental Industrial Hygienists: Threshold limit values for chemical substances in the work environment. Cincinnati: ACGIH, 1987.

34 Gray CN, Gerin M, Fletcher T, Simonato L. Occupational Hygiene Assessment in the Study of Cancer Mortality among Welders. Proceedings of the 8th annual conference of the Australian Institute of Occupational Hygienists, Adelaide: 1990:30-8.

35 International Agency for Research on Cancer. Mortality and cancer incidence follow up of an historical cohort of European welders. Lyon: IARC, 1989. (Internal report 89/003.)

36 Keskinen H, Kalliomäki P-L, Alanko K. Occupational asthma due to stainless steel welding fumes. Clin Allergy 1980;10: 151-9.

Accepted 1 October 1990 